\title{
Bacteriological Contaminants of Some Fresh Vegetables Irrigated with Awetu River in Jimma Town, Southwestern Ethiopia
}

\author{
Desta Weldezgina $^{1}$ and Diriba Muleta ${ }^{2}$ \\ ${ }^{1}$ Department of Biology, College of Natural Sciences, Jimma University, Jimma, Ethiopia \\ ${ }^{2}$ Institute of Biotechnology, Addis Ababa University, Addis Ababa, Ethiopia \\ Correspondence should be addressed to Desta Weldezgina; destaws2005@gmail.com
}

Received 17 February 2016; Accepted 26 April 2016

Academic Editor: Dario De Medici

Copyright (c) 2016 D. Weldezgina and D. Muleta. This is an open access article distributed under the Creative Commons Attribution License, which permits unrestricted use, distribution, and reproduction in any medium, provided the original work is properly cited.

The main purposes of this study were to determine the bacteriological load and safety of some fresh vegetables irrigated with Awetu River in Jimma town, southwestern Ethiopia. Water and vegetable samples were collected from three different irrigation sites and analyzed for their bacteriological contaminants following standard procedures. The maximum overall means of aerobic mesophilic bacteria, Enterobacteriaceae, aerobic spore formers, staphylococci, and total and fecal coliform counts were 8.06, 7.10, 6.54, and $2.97 \log \mathrm{CFU} \mathrm{g}^{-1}$ and 1036 and $716 \mathrm{MPN} 100 \mathrm{~mL}^{-1}$, respectively. The microflora of vegetable samples was dominated by Bacillus species (32.7\%) followed by Enterobacteriaceae (25\%) and Micrococcus (16\%). Staphylococcus aureus and Salmonella spp. were detected in $24.0 \%$ and $20.7 \%$ of the samples, respectively. All the Staphylococcus aureus isolates were resistant to ampicillin, cefuroxime sodium, and penicillin G (100.0\% each). All the Salmonella isolates were also resistant to tetracycline, erythromycin, cefuroxime sodium, and penicillin G (100.0\% each). The findings reveal that the river water used for irrigation in this study is a possible preharvest source of contamination to fresh vegetables which potentially constitutes a health risk to consumers.

\section{Introduction}

Fresh and minimally processed vegetables and fruits provide the most important human diet that contains carbohydrates, proteins, vitamins, minerals, and fiber. Lerici et al. [1] reported that nutritional and other benefits of a regular intake of fruits and vegetables are well documented internationally. Their role in reducing the risk of lifestyle associated illnesses such as heart disease, diabetes, and cancer has resulted in a further increase in desirability and consumption [2]. For instance, Food and Drug Administration (FDA) and World Health Organization (WHO) have recommended 59 servings of fruits and vegetables to be taken daily because correct fresh produce intake alone could save 2.7 million lives a year [3].

In contrast to their health benefits, the consumption of fresh fruits and vegetables has also been associated to risk for consumers [4]. Outbreaks of food infections associated with consumption of ready-to-eat vegetables have been increasing [5]. Garg et al. [6] show that outbreaks of illness caused by bacteria, viruses, and parasites have been linked epidemiologically to the consumption of a wide range of vegetables and to a lesser extent of fruits. Furthermore, surveillance of vegetables has indicated that these foods can be contaminated with various bacterial pathogens, including Salmonella spp., Shigella spp., Shiga toxigenic E. coli (STEC), Listeria monocytogenes, and Campylobacter spp. [7].

Ijabadeniyi [2] reported that prepackaged fresh spinach was recalled by the Food and Drug Administration (FDA) as a result of E. coli outbreak in California, USA. The author also noted that fresh tomatoes consumed at restaurants in the USA were also blamed for an outbreak of S. typhimurium. In addition, there was an E. coli O157:H7 outbreak linked to lettuce from Taco Bell restaurants in northern USA [8].

The increase in outbreaks of foodborne illnesses due to fresh produce is a result of changes in dietary habits, including a higher per capital consumption of fresh or minimally processed fruits and vegetables and the increased use of 
salad bars and meals eaten outside the home, Ijabadeniyi [2]. Changes in production and processing methods of distribution, consumption patterns, and practices are other factors that have also contributed to increasing foodborne diseases due to raw consumed vegetables [9].

Ijabadeniyi [2] reported that other reasons given by the Food and Agriculture Organization (FAO) and World Health Organization (WHO) [10] for the increasing of foodborne infection/poisoning outbreaks are as follows: microbial adaptation, increase in international trade and in susceptible population, and increase in worldwide travelling. Furthermore, changes of a lifestyle of convenience, consumer demands regarding healthy food with no chemical preservatives and with an extended shelf life, and changes in human demographics and behavior have also contributed to increase of foodborne infections.

According to Suslow et al. [11], the microbial quality of irrigation water is critical because water contaminated with animal or human wastes can introduce pathogens into vegetable products during preharvest and postharvest activities via direct or indirect contamination. Therefore, microbiological quality of irrigation water has a paramount importance to the safety of fresh and minimally processed vegetables [12]. Moreover, Ibenyassine et al. [13] reported that contaminated irrigation water and surface runoff water may be the major sources of pathogenic microorganisms that contaminate fruits and vegetables in fields. Water from the river that received both human and animal waste disposal poses a health risk due to contamination with all microorganisms of human and animal intestinal habitat such as Salmonella and Listeria spp. [14, 15]. Consequently, the microbiological quality and safety of fresh vegetables is a significant concern to all stakeholders all over the world.

Tambekar and Mundhada [16] reported that foodborne bacterial pathogens commonly detected in fresh vegetables were E. coli, S. aureus, and Salmonella spp. Ayçiçek et al. [17] have also stated that plate count of aerobic mesophilic microorganisms found in food is one of the microbiological indicators for food quality in addition to the common indicators such as fecal coliform. Information on the microbial load on fresh vegetables in Ethiopia has been studied by several investigators [18-20].

According to Hailu [21], the use of rivers and handdug wells for various purposes is common in Jimma town. The author further noted that Awetu River is the primary source of water for a range of activities such as recreation, bathing, washing clothes, and household utensils, small scale agricultural irrigation, car washing, and other uses. The deterioration of the quality of Awetu River as a result of discharge of municipal wastes and urban runoff has been well studied, Hailu [21]. For instance, Deneke [22] investigated about the pollution profiles along Awetu River and found high load of fecal coliforms. According to Sofonias and Tsegaye [23] some of the water sources in Jimma town such as unprotected springs, wells, and Awetu River have greater chance to be contaminated via human and animal fecal matters and wastes disposed from households, hotels, and small scale industries. Thus, these water sources could transmit diseases as a result of contamination. However, a comprehensive investigation of the quality and safety of vegetables irrigated with Awetu River including bacteriological quality and safety analyses is lacking. Therefore, this study was aimed at investigating the bacteriological contaminants of some fresh vegetables irrigated with Awetu River, in Jimma town, southwestern Ethiopia.

\section{Materials and Methods}

2.1. Description of the Study Area. The study was conducted at Jimma town, located $350 \mathrm{~km}$ southwest of Addis Ababa. The town's geographical coordinates are $7^{\circ} 41^{\prime} \mathrm{N}$ latitude and $36^{\circ} 50^{\prime} \mathrm{E}$ longitude. The town is found with abundant mean annual rainfall between 1800 and $2300 \mathrm{~mm}$ which makes this region one of the best watered Ethiopian highland areas, conducive for agricultural production [24].

2.2. Study Design and Study Population. Laboratory based cross sectional study design was used. The sampling sites were three irrigation farms around Awetu River designated as site $\mathrm{A}, \mathrm{B}$, and $\mathrm{C}$ along the river course at the same time of the irrigation period. The size of the farms is about 1.5 ha and the average production of vegetables from these farms is $30 \mathrm{~kg} / \mathrm{ha}$. On the average the frequency of irrigation for the target vegetables is 3-5 days/week depending on the humidity of the air at the farms.

There are many farmers who are members of Microenterprise Association around Awetu River. They are actively involved in irrigating their farms.

Preliminary survey was made on the distribution and location of vegetable growers in the study area prior to resuming the actual sample collection. The survey included individual residents and members of Microenterprise Association of vegetable growers who regularly use Awetu River to irrigate their farms in Jimma town. Purposive sampling was made to gather information on Awetu River from a total of 60 vegetable growers using structured questionnaire. This survey was performed in order to get general information about Awetu River including its pollution status and its effect on human health.

2.3. Collection of Samples. A total of 120 vegetable samples, 40 each from the three sites and 10 samples each of lettuce, cabbage, tomato, and carrot, were randomly picked $(1.5 \mathrm{~kg})$ aseptically using sterilized scissors and cut into pieces. In addition, a total of 30 irrigation water samples $(200 \mathrm{~mL}$ each) were collected from three sites (10 samples each). The water samples were collected from the depth of below $5 \mathrm{~cm}$ surface water using sterilized stopper glass bottles. The samples were transported to Postgraduate and Research Laboratory of Biology Department, College of Natural Sciences, Jimma University using ice box. The samples were processed for bacteriological analysis within 1-4 hrs of collection.

2.4. Sample Preparation. Mixed vegetable samples (unprocessed and large sized) were aseptically chopped into smaller pieces using a sterile stainless steel knife prior to weighing. A $25 \mathrm{~g}$ of subsample of each vegetable was aseptically weighed and vigorously shaken in $225 \mathrm{~mL}$ of sterile $0.1 \%(\mathrm{w} / \mathrm{v})$ buffered 
peptone water (Oxoid) for 3 min separately to homogenize the samples [25]. In addition, a tenfold serial dilution was made. A $10 \mathrm{~mL}$ of water sample was also mixed with $90 \mathrm{~mL}$ of peptone water using vortex mixer. Finally, appropriate serial dilutions of the suspension were spread-plated on a suitable solid media.

2.5. Bacterial Counts. A volume of $0.1 \mathrm{~mL}$ aliquot of appropriate dilution was spread-plated in duplicate on presolidified plates of Plate Count Agar (Oxoid), Violet Red Bile Glucose Agar (Oxoid) and Mannitol Salt Agar (Oxoid) that then were incubated at optimum temperature and time for counts of aerobic mesophilic bacteria, Enterobacteriaceae, and staphylococci, respectively. Homogenized samples were heated at $80^{\circ} \mathrm{C}$ for 10 minutes in a water bath to count aerobic spore formers. Thereafter, a $0.1 \mathrm{~mL}$ appropriate dilution was spread-plated in duplicate on predried surfaces of Plate Count Agar (Oxoid) plates. Inoculated plates were incubated at $30^{\circ} \mathrm{C}-32^{\circ} \mathrm{C}$ for $24-48 \mathrm{hrs}$. For microbial counts, plates with colonies between 30 and 300 were considered. Total coliforms and fecal coliforms were enumerated by multiple tube fermentation tests as described by APHA [26]. The results were expressed as MPN $100 \mathrm{~mL}^{-1}$.

2.6. Isolation and Characterization of Dominant Microflora. After enumeration of aerobic mesophilic bacteria, 10-20 colonies with distinct morphological difference such as color, size, and shape were randomly picked from countable plates and aseptically transferred into a tube containing $5 \mathrm{~mL}$ nutrient broth (Oxoid) and incubated at $30^{\circ} \mathrm{C}$ for $24-48 \mathrm{hrs}$. The cultures were purified by repeated plating and pure cultures were temporarily preserved on nutrient agar slants at $4^{\circ} \mathrm{C}$ for a month for further work. An overnight activated culture was further characterized using the following standard tests such as cell morphology, gram staining, motility, bacterial endospore staining, catalase, cytochrome oxidase, and Oxidation Fermentation $(\mathrm{O} / \mathrm{F})$ to differentiate into various bacterial groups such as genus and family levels [27].

2.7. Isolation and Biochemical Identification of Some Bacterial Pathogens. After counting staphylococci, yellow colonies on Mannitol Salt Agar plates were aseptically picked and transferred into $5 \mathrm{~mL}$ nutrient broth and incubated at $37^{\circ} \mathrm{C}$ for 24-36 hrs for further purification. Then, a loop of culture from the nutrient broth was streaked on presolidified surface of nutrient agar supplemented with $0.75 \%$ sodium chloride and again incubated at $37^{\circ} \mathrm{C}$ for $24-36 \mathrm{hrs}$ so as to obtain distinct colonies. Finally, the distinct colonies were characterized using the established microbiological methods such as gram staining. Gram positive cocci with clustered arrangement under the microscope were subjected to preliminary biochemical tests (the catalase and coagulase tests) for conformation.

$25 \mathrm{~g}$ or $25 \mathrm{~mL}$ of each sample was aseptically transferred into sterile flask containing $225 \mathrm{~mL}$ buffered peptone water (BPW), then was homogenized for $5 \mathrm{~min}$, and then was incubated at $37^{\circ} \mathrm{C}$ for $24 \mathrm{hrs}$ for recovery and proliferation of cells. Following the BPW enrichment, a $1 \mathrm{~mL}$ of culture was transferred into $10 \mathrm{~mL}$ of Rappaport Vassiliadis broth and was incubated at $43^{\circ} \mathrm{C}$ for $48 \mathrm{hrs}$. A loop full of culture from the Rappaport Vassiliadis broth was streaked onto Xylose Lysine Deoxycholate Agar (XLD) agar and incubated at $37^{\circ} \mathrm{C}$ for 24 hrs. Typical colonies that appeared red or colorless with no blackening were picked as presumptive Shigella and colonies which had slightly transparent zone of reddish color and a black center, a pink-red zone surrounding the colonies, were considered as presumptive Salmonella. The presumptive Salmonella and Shigella colonies were further confirmed following standard methods [28].

2.8. Antimicrobial Susceptibility Testing for S. aureus and Salmonella spp. The antimicrobial susceptibility testing for S. aureus and Salmonella spp. was determined according to modified Kirby Bauer disc diffusion technique as described by Clinical Laboratory Standard Institute (CLSI; [29]). The following 9 drugs, namely, ampicillin $(10 \mu \mathrm{g})$, gentamycin $(10 \mu \mathrm{g})$, chloramphenicol $(30 \mu \mathrm{g})$, tetracycline $(30 \mu \mathrm{g})$, erythromycin $(15 \mu \mathrm{g})$, Ttrimethoprim-sulfamethoxazole (co-trimoxazole) $(25 \mu \mathrm{g})$, cefuroxime sodium (5 $\mu \mathrm{g})$, norfloxacin $(10 \mu \mathrm{g})$, and penicillin $\mathrm{G}(10 \mu \mathrm{g})$, were used to determine the antibiogram of the isolates. The criteria used to select the antimicrobial agents tested in this study were based on availability and frequency of prescription of the drugs for the management of bacterial infection in Ethiopia. Salmonella typhimurium (ATCC13311) and Staphylococcus aureus (ATCC25923) were used as reference strains for quality control of the antibiotics used.

2.9. Data Analysis. Bacterial counts were calculated as colony forming units per gram $\left(\mathrm{CFU} \mathrm{g}^{-1}\right)$ and colony forming units per milliliter (CFU mL ${ }^{-1}$ ) and converted into $\log _{10}$ values. The statistical analysis was performed by one-way analysis of variance (ANOVA) followed by LSD's Post Hoc Multiple Comparison Test using statistical software (SPSS) package version 21. $p<0.05$ was considered statistically significant.

\section{Results}

3.1. Sociodemographic Characteristics of the Study Subjects. Males accounted for $71.7 \%$ of the respondents (data not shown). The ages of vegetable growers ranged from 18 to 67 years with average age of 35 years. A large number of the respondents $(48.3 \%)$ were Muslims followed by Orthodox (33.3\%). Regarding their marital status, $70 \%$ were married but $21.7 \%$ were unmarried. About $55 \%$ of the respondents were illiterate and the rest (45\%) attended elementary school (data not shown).

3.2. Irrigation Conditions of Awetu River. All the respondents (100.0\%) used Awetu River for different purposes (Table 1). From all the respondents, 98.3\% used Awetu River for irrigation, 35\% for washing their clothes, and the rest $8.3 \%$ for taking shower (Table 1). The majority of the respondents $(96.7 \%)$ irrigated tomato followed by potato $(75.0 \%)$ and carrot $(51.7 \%)$ (Table 1$)$. 
TABLE 1: General information and irrigation conditions of Awetu River.

\begin{tabular}{|c|c|c|}
\hline \multirow[t]{2}{*}{ Characteristics } & \multicolumn{2}{|c|}{$\begin{array}{l}\text { Number of respondents } \\
\qquad(n=60)\end{array}$} \\
\hline & Frequency & Percent (\%) \\
\hline \multicolumn{3}{|c|}{ Using of Awetu River for any means } \\
\hline Yes & 60.0 & 100.0 \\
\hline No & 0.0 & 0.0 \\
\hline \multicolumn{3}{|l|}{ Application of Awetu River } \\
\hline Irrigation & 59.0 & 98.3 \\
\hline Washing clothes & 21.0 & 35.0 \\
\hline Taking shower & 5.0 & 8.3 \\
\hline \multicolumn{3}{|c|}{$\begin{array}{l}\text { Types of vegetables irrigated with Awetu } \\
\text { River }\end{array}$} \\
\hline Tomato & 58.0 & 96.7 \\
\hline Potato & 45.0 & 75.0 \\
\hline Carrot & 31.0 & 51.7 \\
\hline Cabbage & 23.0 & 38.3 \\
\hline Lettuce & 11.0 & 18.3 \\
\hline Green pepper & 6.0 & 10.0 \\
\hline Onion & 4.0 & 6.7 \\
\hline \multicolumn{3}{|l|}{ Use of irrigated vegetables } \\
\hline Family consumption & 53.0 & 88.3 \\
\hline Source of income & 44.0 & 73.3 \\
\hline \multicolumn{3}{|c|}{$\begin{array}{l}\text { Suspected diseases due to consumption } \\
\text { of the vegetables }\end{array}$} \\
\hline Typhoid & 10.0 & 66.7 \\
\hline Diarrhea & 7.0 & 46.7 \\
\hline Anemia & 2.0 & 13.3 \\
\hline \multicolumn{3}{|c|}{$\begin{array}{l}\text { Suffering of Awetu River from any } \\
\text { contamination }\end{array}$} \\
\hline Yes & 60.0 & 100.0 \\
\hline No & 0.0 & 0.0 \\
\hline \multicolumn{3}{|l|}{ Sources of contamination } \\
\hline Wastes released from toilet & 58.0 & 96.7 \\
\hline Domestic waste & 55.0 & 91.7 \\
\hline Plastic and petrol washes & 19.0 & 31.7 \\
\hline Fecal matter & 8.0 & 13.3 \\
\hline
\end{tabular}

A significant number of the growers (88.3\%) used cultivated vegetables for family consumption, while $73.3 \%$ used them as their source of income (Table 1). The respondents complained of health problems due to consumption of the vegetables. Accordingly, some of the respondents suspected typhoid (66.7\%), others diarrhea (46.7\%), and the rest associated the issue with anemia (13.3\%) (Table 1).

Generally, all the respondents $(100.0 \%)$ believed that Awetu River suffers from wastes released from Jimma town that included toilet wastes $(96.7 \%)$, domestic wastes $(91.7 \%)$, plastic and petrol washes (31.67\%), and fecal matter $(13.3 \%$; Table 1).
3.3. Bacterial Counts. The mean bacterial counts $\left(\log\right.$ CFU mL $\mathrm{mL}^{-1}$ or $\left.^{-1}\right)$ of aerobic mesophilic bacteria, Enterobacteriaceae, aerobic spore formers, and staphylococci at the three sites were $8.58,7.42,5.75$, and $2.64 \log \mathrm{CFU} \mathrm{mL} \mathrm{m}^{-1}$ for water; 6.94, 6.09, 5.24, and 2.97 for lettuce; 8.06, 7.10, 6.54, and 2.71 for carrot; 7.41, 6.24, 5.71, and 2.75 for tomato; 7.66, $6.70,5.89$, and $2.76 \log \mathrm{CFU} \mathrm{g}^{-1}$ for cabbage, respectively (Table 2). The mean microbial counts of different samples of selected sites ranged from 2.55 to $9.42 \log \mathrm{CFU} \mathrm{mL}^{-1}$.

The minimal and maximal mean counts of aerobic mesophilic bacteria, Enterobacteriaceae, aerobic spore formers, and staphylococci obtained from different samples of the three sites ranged from 5.92 to $9.42,5.0$ to $8.36,4.30$ to 7.04 , and 2.55 to $3.24 \log \mathrm{CFU} \mathrm{g}^{-1}$ or $\mathrm{mL}^{-1}$, respectively (Table 2). The mean count of $\mathrm{AMB}$ was the highest $\left(9.42 \log \mathrm{CFU} \mathrm{mL} \mathrm{m}^{-1}\right)$ in water samples of site C. The count of Enterobacteriaceae was also relatively higher $\left(8.36 \log \mathrm{CFU} \mathrm{mL}{ }^{-1}\right)$ in water samples of site $\mathrm{C}$ but the range of mean count for staphylococci relatively in all samples was similar (Table 2). In addition, MPN of total and fecal coliforms and their overall mean in vegetables also ranged from 865.3 to 1036.0 and 524.0 to $716.0 \mathrm{MPN} 100 \mathrm{~mL}^{-1}$, respectively. However, both were $>2400.0 \mathrm{MPN} 100 \mathrm{~mL}^{-1}$ in water samples (Table 2).

The mean counts $\left(\log \mathrm{CFU} \mathrm{mL} \mathrm{m}^{-1}\right.$ or $\left.\mathrm{g}^{-1}\right)$ of $\mathrm{AMB}$, Enterobacteriaceae, and aerobic spore formers revealed statistically significant $(p<0.05)$ difference between all samples of the three sites. However, there was no significant $(p>0.05)$ difference between mean counts of total coliform and fecal coliforms of all the samples collected from the three irrigation sites (Table 2). Likewise, the mean counts of staphylococci did not differ significantly $(p>0.05)$ between the different site of irrigation farms for carrot and cabbage (Table 2). Mean counts of all bacterial groups differed significantly $(p<0.05)$ between the different sample types with the highest mean count in carrot samples (data not shown).

3.4. Microflora Analysis. Aerobic mesophilic bacterial flora of water samples collected from the three sites of the downstream of Awetu River was dominated by Bacillus spp. (35.3\%), Enterobacteriaceae (26.7\%), Micrococcus spp. (12.0), Pseudomonas spp. (8.3\%), Staphylococcus spp. (6.7\%), Aeromonas spp. (6.0\%), and Streptococcus spp. (5.0\%). Similarly, the most predominant genera/families in lettuce, carrot, tomato, and cabbage samples were Bacillus spp. (30.0, 34.0, 31.7, and 32.3\%), Enterobacteriaceae (23.3, 26.0, 24.0, and 25.0\%), Micrococcus spp. (16.0, 16.3, 18.7, and 17.3\%), Pseudomonas spp. (13.0, 9.0 10.3, and 9.3\%), Staphylococcus spp. (9.3, 6.7, 8.0, and 8.7\%), Aeromonas spp. (6.0, 5.0 5.7, and 5.0\%), and Streptococcus spp. (2.3, 3.0, 1.7, and 2.3\%), respectively (Figure 1). Generally, the same dominant genera were isolated in both water and vegetable samples even though their distributions were relatively varied.

3.5. Prevalence of S. aureus, Shigella, and Salmonella Isolates. The total prevalence of S. aureus and Salmonella was $24.0 \%$ and $20.7 \%$, respectively (Table 3 ). The distribution of these pathogens varied depending on the nature of vegetables. With regard to sample types, prevalence of $S$. aureus was higher 
TABLE 2: Bacterial counts from water and vegetable samples.

\begin{tabular}{|c|c|c|c|c|c|c|c|}
\hline \multirow{2}{*}{ Sample type } & \multirow{2}{*}{ Site } & \multicolumn{4}{|c|}{ Average $\log \mathrm{CFU} \mathrm{mL} \mathrm{m}^{-1}$ or $\mathrm{G}^{-1} \pm$ S.D } & \multicolumn{2}{|c|}{ Average MPN $100 \mathrm{~mL}^{-1} \pm$ S.D. } \\
\hline & & AMB & Entero. & ASFs & Staph. & Total coliform & Fecal coliform \\
\hline \multirow{4}{*}{ Water } & A & $7.65^{\mathrm{c}} \pm 0.4$ & $6.55^{\mathrm{c}} \pm 0.3$ & $4.88^{\mathrm{c}} \pm 0.5$ & $2.55^{\mathrm{b}} \pm 0.1$ & $>2400.00^{\mathrm{a}} \pm 0$ & $>2400.00^{\mathrm{a}} \pm 0$ \\
\hline & $\mathrm{B}$ & $8.69^{\mathrm{b}} \pm 0.5$ & $7.34^{b} \pm 0.3$ & $5.70^{\mathrm{b}} \pm 0.5$ & $2.66^{\mathrm{ab}} \pm 0.1$ & $>2400.00^{\mathrm{a}} \pm 0$ & $>2400.00^{\mathrm{a}} \pm 0$ \\
\hline & $\mathrm{C}$ & $9.42^{\mathrm{a}} \pm 0.1$ & $8.36^{\mathrm{a}} \pm 0.1$ & $6.65^{\mathrm{a}} \pm 0.5$ & $2.71^{\mathrm{a}} \pm 0.1$ & $>2400.00^{\mathrm{a}} \pm 0$ & $>2400.00^{\mathrm{a}} \pm 0$ \\
\hline & Average & $8.58 \pm 0.3$ & $7.42 \pm 0.2$ & $5.75 \pm 0.5$ & $2.64 \pm 0.1$ & $>2400.00 \pm 0$ & $>2400.00 \pm 0$ \\
\hline \multirow{4}{*}{ Lettuce } & $\mathrm{A}$ & $5.92^{\mathrm{c}} \pm 0.5$ & $5.00^{c} \pm 0$ & $4.30^{\mathrm{c}} \pm 0.1$ & $2.77^{\mathrm{b}} \pm 0.2$ & $844.00^{\mathrm{a}} \pm 330.5$ & $524.00^{\mathrm{a}} \pm 202.4$ \\
\hline & $\mathrm{B}$ & $6.90^{\mathrm{b}} \pm 0.5$ & $6.10^{\mathrm{b}} \pm 0.6$ & $5.41^{\mathrm{b}} \pm 0.3$ & $2.89^{\mathrm{b}} \pm 0.3$ & $908.00^{\mathrm{a}} \pm 309.1$ & $588.00^{\mathrm{a}} \pm 269.8$ \\
\hline & $\mathrm{C}$ & $7.99^{\mathrm{a}} \pm 0.5$ & $7.17^{\mathrm{a}} \pm 0.4$ & $6.02^{\mathrm{a}} \pm 0.5$ & $3.24^{\mathrm{a}} \pm 0.4$ & $972.00^{\mathrm{a}} \pm 269.8$ & $652.00^{\mathrm{a}} \pm 309.1$ \\
\hline & Average & $6.94 \pm 0.5$ & $6.09 \pm 0.3$ & $5.24 \pm 0.3$ & $2.97 \pm 0.3$ & $908 \pm 303.2$ & $588 \pm 260.5$ \\
\hline \multirow{4}{*}{ Carrot } & $\mathrm{A}$ & $7.05^{c} \pm 0.5$ & $6.43^{c} \pm 0.3$ & $5.98^{\mathrm{c}} \pm 0.4$ & $2.63^{\mathrm{a}} \pm 0.1$ & $972.00^{\mathrm{a}} \pm 269.8$ & $652.00^{\mathrm{a}} \pm 309.1$ \\
\hline & B & $7.99^{b} \pm 0.5$ & $7.08^{b} \pm 0.4$ & $6.59^{\mathrm{b}} \pm 0.4$ & $2.74^{\mathrm{a}} \pm 0.1$ & $1036.00^{\mathrm{a}} \pm 202.4$ & $716.00^{\mathrm{a}} \pm 330.5$ \\
\hline & $\mathrm{C}$ & $9.15^{\mathrm{a}} \pm 0.4$ & $7.79^{\mathrm{a}} \pm 0.5$ & $7.04^{a} \pm 0.5$ & $2.76^{\mathrm{a}} \pm 0.2$ & $1100.00^{\mathrm{a}} \pm 0$ & $780.00^{\mathrm{a}} \pm 337.3$ \\
\hline & Average & $8.06 \pm 0.5$ & $7.1 \pm 0.4$ & $6.54 \pm 0.5$ & $2.71 \pm 0.2$ & $1036 \pm 157.4$ & $716 \pm 325.7$ \\
\hline \multirow{4}{*}{ Tomato } & $\mathrm{A}$ & $6.57^{c} \pm 0.4$ & $5.38^{\mathrm{c}} \pm 0.4$ & $5.12^{c} \pm 0.4$ & $2.62^{c} \pm 0.1$ & $780.00^{\mathrm{a}} \pm 460$ & $460.00^{\mathrm{a}} \pm 0$ \\
\hline & B & $7.53^{b} \pm 0.4$ & $6.34^{\mathrm{b}} \pm 0.3$ & $5.72^{b} \pm 0.5$ & $2.76^{\mathrm{b}} \pm 0.1$ & $844.00^{\mathrm{a}} \pm 330.5$ & $524.00^{\mathrm{a}} \pm 202.4$ \\
\hline & C & $8.12^{\mathrm{a}} \pm 0.4$ & $6.99^{\mathrm{a}} \pm 0.5$ & $6.29^{\mathrm{a}} \pm 0.1$ & $2.88^{\mathrm{a}} \pm 0.1$ & $972.00^{\mathrm{a}} \pm 269.8$ & $588.00^{\mathrm{a}} \pm 269.8$ \\
\hline & Average & $7.41 \pm 0.4$ & $6.24 \pm 0.4$ & $5.71 \pm 0.3$ & $2.75 \pm 0.1$ & $865.33 \pm 353.4$ & $524 \pm 157.4$ \\
\hline \multirow{4}{*}{ Cabbage } & $\mathrm{A}$ & $6.82^{c} \pm 0.5$ & $5.89^{c} \pm 0.5$ & $5.24^{c} \pm 0.3$ & $2.71^{\mathrm{a}} \pm 0.2$ & $844.00^{\mathrm{a}} \pm 330.5$ & $588.00^{\mathrm{a}} \pm 269.8$ \\
\hline & B & $7.58^{\mathrm{b}} \pm 0.4$ & $6.81^{b} \pm 0.5$ & $5.81^{b} \pm 0.5$ & $2.73^{\mathrm{a}} \pm 0.2$ & $908.00^{\mathrm{a}} \pm 309.1$ & $652.00^{\mathrm{a}} \pm 309.1$ \\
\hline & $\mathrm{C}$ & $8.57^{\mathrm{a}} \pm 0.4$ & $7.40^{\mathrm{a}} \pm 0.5$ & $6.63^{a} \pm 0.5$ & $2.85^{\mathrm{a}} \pm 0.2$ & $1036.00^{\mathrm{a}} \pm 202.4$ & $716.00^{\mathrm{a}} \pm 330.5$ \\
\hline & Average & $7.66 \pm 0.4$ & $6.7 \pm 0.5$ & $5.89 \pm 0.4$ & $2.76 \pm 0.2$ & $929.33 \pm 280.7$ & $652 \pm 303.2$ \\
\hline
\end{tabular}

Mean values followed by different alphabets within a column of each sample types are significantly different using post hoc multiple comparisons test $(p<0.05)$, where AMB stands for aerobic mesophilic bacteria, ASFs, aerobic spore formers, Entero., Enteriobacteriaceae, and Staph., staphylococci.

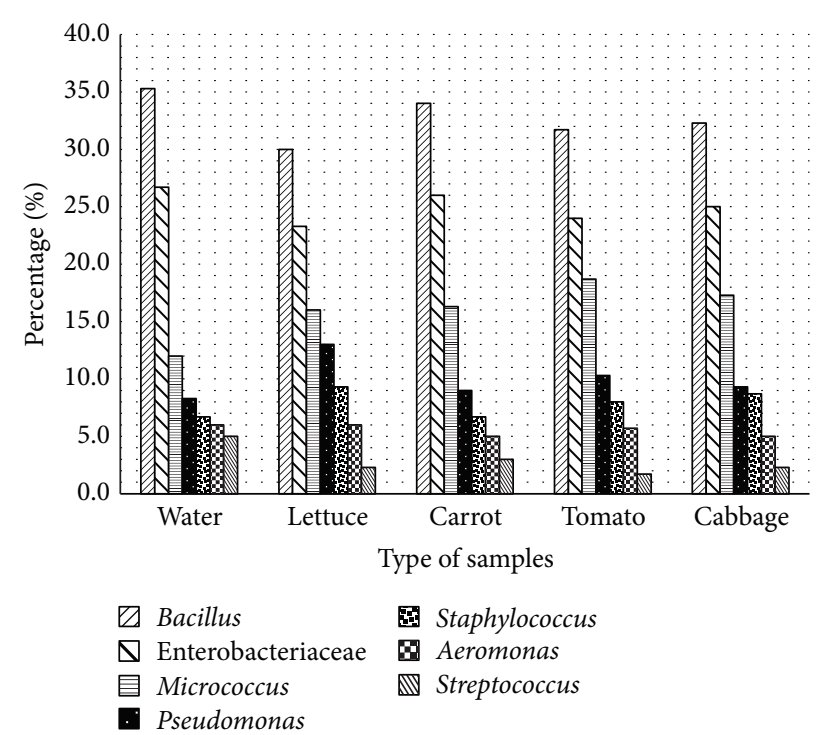

FIGURE 1: Distribution of dominant bacterial isolates from water and vegetable samples from irrigated farm land along the Awetu River.

in lettuce (33.3\%), cabbage (26.7\%), and tomato (23.3\%), but relatively lower in water $(20.0 \%)$ and carrot samples (16.7\%). Higher frequency of Samonella spp. was encountered in cabbage (30.0\%) but it was lower in lettuce (13.3\%, Table 3). Shigella was not encountered in any of the samples analyzed. The prevalence of these all bacterial pathogens was not significantly $(p>0.05)$ different with respect to sample types (data not shown). However, in terms of sample sites, there was significant $(p<0.05)$ difference for $S$. aureus but not for Salmonella spp. (data not shown).

3.6. Antimicrobial Susceptibility Patterns of S. aureus and Salmonella Isolates. Staphylococcus aureus isolates were most susceptible to chloramphenicol (100.0\%), norfloxacin (94.4.0\%), gentamycin (86.1\%), and erythromycin (80.6\%; Table 4). Out of the tested drugs, the highest resistance was observed against ampicillin, cefuroxime sodium, and penicillin G (100.0\% each).

All Salmonella isolates were also susceptible to chloramphenicol, norfloxacin, gentamycin $(100.0 \%$ each), and cotrimoxazole (93.5\%). Out of the tested drugs, the highest resistance was observed against tetracycline, erythromycin, cefuroxime sodium, penicillin G (100.0\% each), and ampicillin $(90.3 \%)$ (Table 4$)$.

3.7. Multiple Drug Resistance of S. aureus and Salmonella Isolates. Pattern of multiple drug resistance (MDR) among $S$. aureus isolates varied from three to seven antibiotics (Table 5). The highest MDR noted was Amp/Pen/Cef/Te/ Cot (11/36, 30.6\%), followed by Amp/Pen/Cef and Amp/Pen/ $\mathrm{Cef} / \mathrm{Te}$ (7/36, 19.4\% each). The maximum MDR registered was resistance to 7 antibiotics with the combination Amp/Pen/Cef/Te/Cot/Ery/Nor. MDR to five antibiotics dominated the resistance patterns $(13 / 36,36.1 \%$; Table 5$)$. 
TABLE 3: Prevalence of S. aureus and Salmonella isolates from water and vegetable samples.

\begin{tabular}{|c|c|c|c|c|}
\hline Sample type & Sites & Sample size & $\begin{array}{l}\text { Number of S. aureus } \\
\text { positive samples (\%) }\end{array}$ & $\begin{array}{c}\text { Number of Salmonella } \\
\text { positive samples (\%) }\end{array}$ \\
\hline \multirow{4}{*}{ Water } & $\mathrm{A}$ & 10 & 0 & 0 \\
\hline & $\mathrm{B}$ & 10 & $2(20)$ & $2(20)$ \\
\hline & C & 10 & $4(40)$ & $5(50)$ \\
\hline & Subtotal & 30 & $6(20)$ & $7(23.3)$ \\
\hline \multirow{4}{*}{ Lettuce } & $\mathrm{A}$ & 10 & $3(30)$ & $1(10)$ \\
\hline & $\mathrm{B}$ & 10 & $2(20)$ & $1(10)$ \\
\hline & C & 10 & $5(50)$ & $2(20)$ \\
\hline & Subtotal & 30 & $10(33.3)$ & $4(13.3)$ \\
\hline \multirow{4}{*}{ Carrot } & A & 10 & 0 & $1(10)$ \\
\hline & B & 10 & $1(10)$ & $2(20)$ \\
\hline & C & 10 & $4(40)$ & $2(20)$ \\
\hline & Subtotal & 30 & $5(16.7)$ & $5(16.7)$ \\
\hline \multirow{4}{*}{ Tomato } & $\mathrm{A}$ & 10 & $1(10)$ & $1(10)$ \\
\hline & $\mathrm{B}$ & 10 & $3(30)$ & $2(20)$ \\
\hline & C & 10 & $3(30)$ & $3(30)$ \\
\hline & Subtotal & 30 & $7(23.3)$ & $6(20)$ \\
\hline \multirow{5}{*}{ Cabbage } & $\mathrm{A}$ & 10 & $1(10)$ & $2(20)$ \\
\hline & B & 10 & $3(30)$ & $3(30)$ \\
\hline & C & 10 & $4(40)$ & $4(40)$ \\
\hline & Subtotal & 30 & $8(26.7)$ & $9(30)$ \\
\hline & Total & 150 & $36(24)$ & $31(20)$ \\
\hline
\end{tabular}

TABLE 4: Antibiotic susceptibility of S. aureus and Salmonella spp. isolated from water and vegetable samples.

\begin{tabular}{|c|c|c|c|c|c|c|c|c|c|}
\hline \multirow{2}{*}{ Antimicrobial agent } & \multirow{2}{*}{ Disc content $(\mu \mathrm{g})$} & \multicolumn{4}{|c|}{ S. aureus $(n=36)$} & \multicolumn{4}{|c|}{ Salmonella spp. $(n=31)$} \\
\hline & & $S$ & $\%$ & $\mathrm{R}$ & $\%$ & S & $\%$ & $\mathrm{R}$ & $\%$ \\
\hline Ampicillin & 10 & 0 & 0 & 36 & 100 & 3 & 9.7 & 28 & 90.3 \\
\hline Gentamycin & 10 & 31 & 86.1 & 5 & 13.9 & 31 & 100 & 0 & 0 \\
\hline Chloramphenicol & 30 & 36 & 100 & 0 & 0 & 31 & 100 & 0 & 0 \\
\hline Tetracycline & 30 & 7 & 19.4 & 29 & 80.6 & 0 & 0 & 31 & 100 \\
\hline Erythromycin & 15 & 29 & 80.6 & 7 & 19.4 & 0 & 0 & 31 & 100 \\
\hline Co-trimoxazole & 25 & 18 & 50 & 18 & 50 & 29 & 93.5 & 2 & 6.5 \\
\hline Cefuroxime sodium & 5 & 0 & 0 & 36 & 100 & 0 & 0 & 31 & 100 \\
\hline Penicillin & 10 & 0 & 0 & 36 & 100 & 0 & 0 & 31 & 100 \\
\hline Norfloxacin & 10 & 34 & 94.4 & 2 & 5.6 & 31 & 100 & 0 & 0 \\
\hline
\end{tabular}

Where $\mathrm{S}$ stands for sensitive and $\mathrm{R}$, resistance.

Pattern of multiple drug resistance (MDR) in Salmonella isolates also varied from four to six antibiotics (Table 5). The highest MDR noted was Amp/Te/Ery/Pen/Cef (26/31, 83.9\%), followed by Te/Ery/Pen/Cef (3/31, 9.7\%). The maximum MDR registered was resistance to 6 antibiotics with the combination of Amp/Te/Ery/Pen/Cef/Cot (Table 5).

\section{Discussion}

In the current study, all the respondents used Awetu River without any treatment for different purposes, mainly for irrigation of vegetables that may be eaten raw. Similarly, Prabu
[30] reported that many people used Akaki River in Addis Ababa, Ethiopia, for different activities including irrigation of vegetables that are served in the households of Addis Ababa city without any treatment.

Some of the respondents complained of health problems such as typhoid due to consumption of vegetables irrigated with Awetu River. Faruqui et al. [31] demonstrated the prevalence of typhoid epidemics in Santiago and Dakar, Senegal, which could be traced to fecal contamination of water or fresh vegetables as noted in this study. Moreover, in agreement with the current study, Gerardi and Zimmerman [32] reported Clostridium perfringes, Staphylococcus aureus, and some other bacteria from wastewater. 
TABLE 5: Multiple drug resistance (MDR) of S. aureus and Samonella spp. isolated from water and vegetable samples.

\begin{tabular}{|c|c|c|c|c|}
\hline \multirow{2}{*}{ Isolates } & \multirow{2}{*}{$\begin{array}{c}\text { Number of } \\
\text { drugs resisted }\end{array}$} & \multirow{2}{*}{ Drugs resisted } & \multicolumn{2}{|c|}{ Resistant isolates } \\
\hline & & & Subtotal number (\%) & Total Number (\%) \\
\hline \multirow{8}{*}{ S. aureus (36 isolates) } & Three & Amp/Cef/Pen & $7(19.4)$ & $7(19.4)$ \\
\hline & Four & $\mathrm{Amp} / \mathrm{Te} / \mathrm{Cef} / \mathrm{Pen}$ & $7(19.4)$ & $7(19.4)$ \\
\hline & \multirow{2}{*}{ Five } & $\mathrm{Amp} / \mathrm{Te} / \mathrm{Cot} / \mathrm{Cef} / \mathrm{Pen}$ & $11(30.6)$ & \multirow{2}{*}{$13(36.1)$} \\
\hline & & Amp/Gen/Te/Cef/Pen & $2(5.6)$ & \\
\hline & \multirow{3}{*}{ Six } & Amp/Te/Ery/Cot/Cef/Pen & $4(11.1)$ & \multirow{3}{*}{$7(19.4)$} \\
\hline & & Amp/Gen/Te/Ery/Cef/Pen & $1(2.8)$ & \\
\hline & & Amp/Gen/Te/Cot/Cef/Pen & $2(5.6)$ & \\
\hline & Seven & Amp/Te/Ery/Cot/Cef/Pen/Nor & $2(5.6)$ & $2(5.6)$ \\
\hline \multirow{3}{*}{ Salmonella spp. (31 isolates) } & Four & Te/Ery/Pen/Cef & $3(9.7)$ & $3(9.7)$ \\
\hline & Five & Te/Ery/Pen/Cef/Amp & $26(83.9)$ & $26(83.9)$ \\
\hline & Six & Te/Ery/Pen/Cef/Amp/Cot & $2(6.5)$ & $2(6.5)$ \\
\hline
\end{tabular}

Where Amp stands for ampicillin, Pen, penicillin, Cef, cefuroxime sodium, Te, tetracycline, Cot, co-trimoxazole, Gen, gentamycin, Ery, erythromycin, and Nor, norfloxacin.

The overall mean aerobic mesophilic count observed in this study ranged from 6.94 to $8.06 \log \mathrm{CFU} \mathrm{g}^{-1}$, relatively higher than previous reports from Morocco, Ibenyassine et al. [33], but other studies reported a lower count that ranged from 2 to $6 \log \mathrm{CFU} \mathrm{g}^{-1}[17,34,35]$. Generally, there is no specification set for the permissible level of microbes for raw food being served in Ethiopia. However, Hazard Analysis and Critical Control Points-Total Quality Management (HACCPTQM) Technical Guidelines lay down the microbial quality for raw foods, where the food containing less than 4, 4$6.69,6.69-7.69$ and greater than $7.69 \log \mathrm{CFU} \mathrm{g}^{-1}$ (aerobic plate count) is rated as good, average, poor, and spoiled food, respectively [36].

According to this guideline specifically the mean counts of AMB in all food samples (this study) were 6.94 $\log \mathrm{CFU} \mathrm{g}^{-1}$ and above. Hence, they belong to the category of poor and spoiled food. Aerobic organisms reflect the exposure of the sample to contamination and the existence of favorable conditions for multiplication of microorganisms [37]. Ayçiçek et al. [17] also stated that plate count of aerobic mesophilic microorganisms found in food is one of the microbiological indicators for food quality, and most foods are regarded as harmful when they have large populations of aerobic mesophilic microorganisms, even if the organisms are not known to be pathogens [38].

The overall mean count of Enterobacteriaceae in the present study ranged from 6.09 to $7.10 \log \mathrm{CFU} \mathrm{g}^{-1}$. This is higher than other studies conducted on lettuce and green pepper 5.08 and $4.84 \log \mathrm{CFU} \mathrm{g}^{-1}$, respectively, by Guchi and Ashenafi [20] and Ibenyassine et al. [33], in Ethiopia and Morocco, respectively. According to Gilbert et al. [39] and guideline recommended for fresh fruit and vegetables in London, overall mean counts $\left(\log \mathrm{CFU} \mathrm{g}^{-1}\right)$ of Enterobacteriaceae in carrot (7.10), cabbage (6.70), tomato (6.24), and lettuce (6.09) revealed unsatisfactory level ( $\geq 4 \log$ CFU g $^{-1}$ ). Guchi and Ashenafi [20] suggested that the high level of
Enterobactericeae in vegetables might indicate that the water used for irrigation could be heavily contaminated with fecal matter from sewerage effluent. Although most of Enterobacteriaceae are normal flora of vegetables, Motarjemi et al. [40] stated that high number clearly proves that poor hygiene could be a source of foodborne pathogens.

In case of aerobic spore formers, the overall mean counts ranged from 5.24 to $6.54 \log \mathrm{CFU} \mathrm{g}^{-1}$. In all vegetables the counts were higher compared to reports by Guchi and Ashenafi [20] where the counts ranged between 3.47 and $3.50 \log \mathrm{CFU} \mathrm{g}^{-1}$ in green pepper and lettuce, respectively, from Addis Ababa, Ethiopia.

In the present study, the overall mean count of staphylococci from vegetable samples ranged from 2.71 to $2.97 \log \mathrm{CFU} \mathrm{g}^{-1}$. This is lower than the microbiological studies made on lettuce and green pepper from super market in Addis Ababa, Ethiopia, Guchi and Ashenafi [20], who reported 4.55 and $4.97 \log \mathrm{CFU} \mathrm{g}^{-1}$, respectively. Higher counts of staphylococci from super market may be due to skin contact and environmental contamination. In the current study, although the counts of staphylococci were low, health risk cannot be avoided, since Erkan et al. [41] reported that contamination of food stuffs during distribution and handling may allow bacterial growth and subsequent production of toxins.

The overall mean counts of total and fecal coliforms from vegetable samples in the present study are relatively lower than Nipa et al. [42], who reported $>1100 \mathrm{MPN}^{100 \mathrm{~mL}^{-1}}$ from salad vegetables. In addition, the current finding is lower than the results obtained by Ashenafi [18], who reported

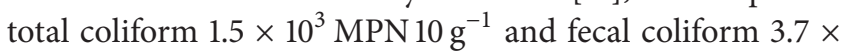
$10^{2} \mathrm{MPN} 10 \mathrm{~g}^{-1}$ counts of raw consumed food like tomato in Ethiopia. A survey carried out on spring onions, lettuce, and cabbage cultivated with poor quality irrigation water in Ghana also showed heavy contamination with fecal coliform between $4.0 \times 10^{3}$ and $9.3 \times 10^{8} \mathrm{MPN} \mathrm{g}^{-1}$ [43]. The observed 
difference in counts can be attributed in part to the degree of original contamination, storage conditions, and the hygienic conditions of utensils and vegetables handlers.

The total and fecal coliform counts from water samples in the present study were $>2400 \mathrm{MPN} 100 \mathrm{~mL}^{-1}$ which is higher than the WHO recommended standard [10]. According to the standard, the fecal coliform level must not exceed 1000 counts $100 \mathrm{~mL}^{-1}$ for the safe use of wastewater for irrigation of vegetables. A relationship has been established between coliform levels and the incidence of pathogenic bacteria like Salmonella [44].

Microbial groups that belong to seven genera were isolated from the examined samples at varying percentages with gram positive and gram negative flora accounting for $59.5 \%$ and $40.5 \%$, respectively. The gram positive cells were represented by bacteria from the genera: Bacillus, Micrococcus, Staphylococcus, and Streptococcus spp. while the gram negative microflora constituted members of Enterobacteriaceae, Pseudomonas spp., and Aromonas spp. This is partly similar to the previous reports by Guchi and Ashenafi [20] in lettuce and green pepper from Addis Ababa, Ethiopia. The predominant microflora of fresh vegetables in the present study was generally Bacillus spp. followed by members of Enterobacteriaceae and Micrococcus spp.

The predominance of Bacillus isolates (this study) among the gram positive bacteria is in agreement with Guchi and Ashenafi [20]. Enterobacteriaceae isolates were the dominant microflora among gram negative isolates unlike the previous reports on lettuce and green pepper from Ethiopia which showed the predominance of Pseudomonas isolates, Guchi and Ashenafi [20]. From water samples, Ikpeme et al. [45] also reported the predominant genera that include Bacillus spp. (86.51\%) followed by Pseudomonas spp. (71.23\%) and Aeromonas spp. (52.58\%) from Nigeria similar to the present study. Kwashie [34] also reported dominant bacteria such as Enterobacteriaceae, Bacillus spp., Staphylococcus spp., Pseudomonas spp., and Clostridium spp. from soil samples irrigated with wastewater. This could be due to direct transfer of bacterial cells from wastewater to soil which may eventually be internalized into the vegetables indicating serious consumer's health risk when consumed raw.

The predominance of Bacillus spp. was possibly due to the presence of spores in the water and soil as well as other environmental factors. The survival of Bacillus depends on several factors such as nature of the organism, resistance to a new physical environment, and ability to form spores [46]. High number of Bacillus spp. could cause food poisoning. In addition, endospores of Bacillus are more resistant than the vegetative cells to harsh weather conditions and even to antimicrobial treatments [47]. Therefore, the presence of high percentage of Bacillus spp. in fresh vegetables could have consumer's health risk.

The predominant Enterobacteriaceae in the present study indicates that the water used for irrigation was heavily contaminated with fecal matter and received sewerage from diverse sources. In addition, fresh fruit and vegetables often carry high levels of Enterobacteriaceae as part of their normal flora, Gilbert et al. [39]. In the present study, Micrococcus spp. was among the dominant isolates due to its occurrence in the wastewater and soil [48]. This is in agreement with Guchi and Ashenafi [20] who reported that Micrococcus spp. are the second dominant microflora isolated from lettuce and green pepper in Addis Ababa, Ethiopia. Micrococcus spp. are common environmental bacteria that could be introduced into the fresh vegetables through cross-contamination, for instance, from wastewater used by the growers during irrigation. Micrococcus is generally thought to be a saprotrophic or commensal organism, though it can be an opportunistic pathogen, particularly in hosts with compromised immune system, such as HIV patients [49].

The prevalence of $S$. aureus in the current study in all vegetables was lower than what is mentioned in the study of Halablab et al. [50] who reported higher prevalence of $S$. aureus (51.5\%) from Lebanon. In addition, Ijabadeniyi [2] also reported $67.0 \%$ in broccoli and $33.0 \%$ in cauliflower in South Africa. The presence of low S. aureus (20.0\%) in the irrigation water in this study was of lower results than those obtained by Ikpeme et al. [45] (25-33\%) from two rivers that are used for irrigation of vegetables in South Africa.

Shigella was not isolated from any of the samples tested in the current study. This is in line with Soriano et al. [51], who reported $(0.0 \%)$ Shigella in all of the lettuces served in Spain University restaurants. However, Shigella was isolated from $8(12.5 \%)$ samples of lettuces and $16(25.0 \%)$ samples of green peppers by Guchi and Ashenafi [20] from super market of Addis Ababa, Ethiopia.

In the present study, the prevalence of Salmonella spp. in all vegetable samples was higher than in other reports by Guchi and Ashenafi [20] and Ijabadeniyi [2] who reported $10 \%$ in lettuce and green peppers as well as $11 \%$ in broccoli and cauliflower, respectively.

In the present study, all the bacterial pathogens isolated from the surface water were also isolated from all vegetables even if their prevalence was varied similar to the reports by Ijabadeniyi [2] in South Africa. Diverse prevalence of pathogens in different samples shows the possibility of variations in surface characteristics of the produce affecting pathogen attachment and survival [52].

The antibiotic resistance patterns of $S$. aureus isolates in the current study showed low percentage of resistance to norfloxacin $(5.6 \%)$, gentamycin $(13.9 \%)$, and erythromycin (19.4\%). This is partly similar to previous report by Donokor et al. [53] from Ghana. In the current study, all S. aureus isolates were resistant to penicillin $\mathrm{G}$, ampicillin, and cefuroxime sodium (100.0\% each). This finding is partly in agreement with Sina et al. [54].

In the present study, high number of Salmonella spp. was susceptible to norfloxacin, chloramphenicol, and gentamycin (100\% each) followed by co-trimoxazole (93.5\%). This result is fairly in line with Akbarmehr [55] who reported that Salmonella spp. were highly susceptible to chloramphenicol (100\%) followed by gentamycin (91.89\%). However, isolates of Salmonella spp. exhibited resistance to tetracycline, erythromycin, penicillin $\mathrm{G}$, and cefuroxime sodium (100\% each) followed by ampicillin (90.3\%). Cardoso et al. [56] have also reported $100 \%$ resistance of Salmonella enteritidis to both tetracycline and erythromycin from Brazil. The marked resistance of strains of Salmonella spp. to ampicillin as shown 
in the present study agrees with the findings of Ash et al. [57] and Ikpeme et al. [45], working on rivers in the United States and Nigeria, respectively.

In this study, the two bacterial pathogens investigated ( $S$. aureus and Salmonella spp.) showed high levels of multiple drug resistance. This trend has also been reported especially in the developing world $[58,59]$.

Generally, the surface water pollution in this study may have originated from both human and animal sewage disposal by the informal settlement that lacks proper sanitation. According to van Vuuren [60], lack of proper sanitation usually leads to disposal of both human and animal wastes in the wrong places including surface water. Almost any ready-to-eat vegetables that have been contaminated with pathogens either from the environment or from human or animal faeces or through storage, processing, and handling could potentially cause disease [4]. As a result consumption of these vegetables with elevated levels of bacterial pathogens may lead to health disorders. Thus regular monitoring of microbial contamination of vegetables grown using wastewater is necessary and consumption of contaminated vegetables should be avoided in order to reduce the health risk.

\section{Conclusion}

The present study showed the potential hazard of fresh vegetables collected from Jimma town which were irrigated with Awetu River. The hygienic quality of both water and vegetable samples was poor since higher mean bacterial counts were recorded beyond the standard safe limits. Microflora of vegetable and water samples was dominated by Bacillus and Enterobacteriaceae. The presence of high number of pathogenic bacteria such as S. aureus and Salmonella spp. could cause foodborne diseases. Ampicillin, penicillin G, and cefuroxime sodium were the most resistant antimicrobial agents by $S$. aureus and Salmonella spp. However, chloramphenicol, norfloxacin, and gentamycin are the drug of choice to be recommended for the treatment of both $S$. aureus and Salmonella spp. according to the in vitro assay of the present study. Wastewater should be properly treated when used for produce that may be eaten raw. This safety measure should be combined with Good Agricultural Practices during production of fresh vegetables. It is important to thoroughly wash vegetables and dip them in food grade antibacterial chemicals for a good time to eliminate pathogens and significantly reduce the microbial load.

\section{Competing Interests}

The authors declare that they have no competing interests.

\section{Acknowledgments}

The financial support of Jimma University is gratefully acknowledged. The authors also would like to thank the farmers of the study area and all individuals that have rendered help and support to this work.

\section{References}

[1] C. R. Lerici, M. C. Nicoli, and M. Anese, “The "weight" given to food processing at the "Food and Cancer Prevention III" symposium," Italian Journal of Food Science, vol. 12, no. 1, pp. $3-7,2000$.

[2] O. A. Ijabadeniyi, Effect of irrigation water quality on the microbiological safety of fresh vegetables [Ph.D. thesis], Pretoria University of Agricultural and Food Sciences, Johannesburg, South Africa, 2010.

[3] L. M. Johnston, C. L. Moe, D. Moll, and L. A. Jaykus, "The epidemiology of produce associated outbreaks of foodborne disease," in Microbial Hazard Identification in Fresh Fruit and Vegetables, J. James, Ed., John Wiley \& Sons, New York, NY, USA, 2006.

[4] L. R. Beuchat, "Ecological factors influencing survival and growth of human pathogens on raw fruits and vegetables," Microbes and Infection, vol. 4, no. 4, pp. 413-423, 2002.

[5] L. Pezzoli, R. Elson, C. L. Little et al., "Packed with Salmonella Investigation of an intestinal outbreak of Salmonella infection linked to contamination of pre-packed basil in 2007," Foodborne Pathogens and Disease, vol. 5, no. 5, pp. 661-668, 2008.

[6] N. Garg, K. L. Garg, and K. G. Mukerji, Laboratory Manual of Food Microbiology, I.K. International Publishing House, New Delhi, India, 2010.

[7] European Commission (E.C.), Risk Profile on the Microbiological Contamination of Fruits and Vegetables Eaten Raw. Report of the Scientific Committee on Food, SCF/CS/FMH/SURF/Final, 2002, http://ec.europa.eu/food/fs/sc/scf/out125_en.pdf.

[8] Centers For Disease Control And Prevention (CDC), "Food borne outbreak online database," 2015, http://www.outbreakdatabase.com/details/taco-bell-restaurants-lettuce-2006/?

[9] L. R. Beuchat and J.-H. Ryu, "Produce Handling and Processing Practices," Emerging Infectious Diseases, vol. 3, no. 4, pp. 459465, 1997.

[10] World Health Organization (WHO), WHO Guidelines for the Safe Use of Wastewater, Excreta and Greywater. Wastewater in Agriculture, vol. 2, World Health Organization, Geneva, Switzerland, 2006.

[11] T. V. Suslow, M. P. Oria, L. R. Beuchat et al., "Production practices as risk factors in microbial food safety of fresh and fresh-cut produce," Comprehensive Reviews in Food Science and Food Safety, vol. 2, no. 1, pp. 38-77, 2003.

[12] E. B. Solomon, C. J. Potenski, and K. R. Matthews, "Effect of irrigation method on transmission to and persistence of Escherichia coli O157:H7 on lettuce," Journal of Food Protection, vol. 65, no. 4, pp. 673-676, 2002.

[13] K. Ibenyassine, R. AitMhand, Y. Karamoko, N. Cohen, and M. M. Ennaji, "Use of repetitive DNA sequences to determine the persistence of enteropathogenic Escherichia coli in vegetables and in soil grown in fields treated with contaminated irrigation water," Letters in Applied Microbiology, vol. 43, no. 5, pp. 528533, 2006.

[14] M. P. Combarro, M. González, M. Araujo, A. C. Amezaga, R. A. Sueiro, and M. J. Garrido, "Listeria species incidence and characterisation in a river receiving town sewage from a sewage treatment plant," Water Science and Technology, vol. 35, no. 11-12, pp. 201-204, 1997.

[15] D. C. Johnson, C. E. Enriquez, I. L. Pepper, T. L. Davis, C. P. Gerba, and J. B. Rose, "Survival of Giardia, Cryptosporidium, poliovirus and Salmonella in marine waters," Water Science and Technology, vol. 35, no. 11-12, pp. 261-268, 1997. 
[16] D. H. Tambekar and R. H. Mundhada, "Bacteriological quality of salad vegetables sold in Amravati city (India)," Journal of Biological Sciences, vol. 6, no. 1, pp. 28-30, 2006.

[17] H. Ayçiçek, B. Sarimehmetoğlu, and S. Çakiroğlu, "Assessment of the microbiological quality of meals sampled at the meal serving units of a military hospital in Ankara, Turkey," Food Control, vol. 15, no. 5, pp. 379-384, 2004.

[18] M. Ashenafi, "Microbial load, incidence and antibiotic resistance of some disease-causing microorganisms on raw food items in consumed Ethiopia," MIRCEN Journal of Applied Microbiology and Biotechnology, vol. 5, no. 3, pp. 313-319, 1989.

[19] G. Aberra, T. Frew, T. Asmamaw, G. Mulu, and A. Sisaynesh, "A preliminary study of the microflora level of some fruits and vegetables: pre- and post-preservation," The Ethiopian Journal of Health Development, vol. 5, no. 2, pp. 57-65, 1991.

[20] B. Guchi and M. Ashenafi, "Microbial load, prevalence and antibiograms of salmonellaand shigella in lettuce and green peppers," Ethiopian Journal of Health Sciences, vol. 20, no. 1, pp. 4347, 2010.

[21] D. Hailu, "Pollution status of Awetu stream as it crosses Jimma town, southwest of Ethiopia. Post basic degree project," in Abstracts of All Public Health Faculty Graduate Student Research Projects, Jimma University, Jimma, Ethiopia, 1997.

[22] I. Deneke, Assessment of drinking water quality and pollution profiles along Awetu stream (Jimma) [M.S. thesis], Addis Ababa University, Addis Ababa, Ethiopia, 2006.

[23] K. Sofonias and G. Tsegaye, "Microbial quality of Jimma water supply," Ethiopian Journal of Education and Sciences, vol. 2, no. 1, p. 23, 2006.

[24] A. Alemu, W. Tsegaye, L. Golassa, and G. Abebe, "Urban malaria and associated risk factors in Jimma town, south-west Ethiopia," Malaria Journal, vol. 10, pp. 173-200, 2011.

[25] S. Shalini, Study on Microbiological Aspects of Fresh Fruit and Vegetables (Including Green Leafy Vegetables) in and around National Capital Region (NCR), Bhaskaracharya College of Applied Sciences, New Delhi, India, 2010.

[26] American Public Health Association (APHA), Standard Methods for the Examination of Water and Wastewater, American Public Health Association (APHA), Washington, DC, USA, 21st edition, 2005.

[27] L. John, An introduction to bacterial identification-general principles, 2001, http://www.jlindquist.net.

[28] T. R. Johnson and C. L. Case, Laboratory Experiments in Microbiology, Pearson Education, San Francisco, Calif, USA, 8th edition, 2007.

[29] M. Cheesbrough, District Laboratory Practice in Tropical Countries-Part 2, Cambridge University Press, Cambridge, UK, 2006.

[30] P. C. Prabu, "Impact of heavy metal contamination of Akaki river of Ethiopia on soil and metal toxicity on cultivated vegetable crops," Electronic Journal of Environmental, Agricultural and Food Chemistry, vol. 8, no. 9, pp. 818-827, 2009.

[31] N. I. Faruqui, C. A. Scott, and L. Raschid-Sally, "Confronting the realities of wastewater use in irrigated agriculture: lessons learned and recommendations," in Wastewater Use In Irrigated Agriculture, Confronting the Livelihood and Environmental Realities, C. A. Scott, N. I. Faruqui, and L. Raschid-Sally, Eds., pp. 173-185, CABI, 2004.

[32] M. H. Gerardi and M. C. Zimmerman, Wastewater Pathogens, Wastewater Microbiology Series, Edited by M.H. Gerardi, John Wiley \& Sons, Hoboken, NJ, USA, 2005.
[33] K. Ibenyassine, R. A. Mahand, Y. Karakomo, B. Anajjar, M. Chouibani, and M. M. Enanaji, "Bacterial pathogens recovered from vegetables irrigated by wastewater in Morocco," Journal of Environmental Health, vol. 69, no. 10, pp. 47-51, 2007.

[34] K. C. Kwashie, Microbial analysis of soil samples in a wastewater irrigated vegetable production site: case study at atonsu, kumasi [M.S. thesis], Kwame Nkrumah University of Science and Technology, Kumasi, Ghana, 2009.

[35] A. S. Angelidis, E. N. Chronis, D. K. Papageorgiou, I. I. Kazakis, K. C. Arsenoglou, and G. A. Stathopoulos, "Non-lactic acid, contaminating microbial flora in ready-to-eat foods: a potential food-quality index," Food Microbiology, vol. 23, no. 1, pp. 95-100, 2006.

[36] H. Aycicek, U. Oguz, and K. Karci, "Determination of total aerobic and indicator bacteria on some raw eaten vegetables from wholesalers in Ankara, Turkey," International Journal of Hygiene and Environmental Health, vol. 209, no. 2, pp. 197-201, 2006.

[37] G. Tortora, Microbiology, Benjamin Publishing Co. Inc., New York, NY, USA, 5th edition, 1995.

[38] R. V. Sudershan, P. Rao, and K. Polasa, "Food safety research in India: a review," Asian Journal of Food and Agro-Industry, vol. 2, no. 3, pp. 412-433, 2009.

[39] R. J. Gilbert, J. de Louvois, T. Donovan et al., "Guidelines for the microbiological quality of some ready-to-eat foods sampled at the point of sale," Communicable Disease and Public Health, vol. 3, no. 3, pp. 163-167, 2000.

[40] Y. Motarjemi, F. Kaferstein, G. Moy, and F. Quevedo, "Contaminated weaning food: a major risk factor for diarrhoea and associated malnutrition," Bulletin of the World Health Organization, vol. 71, no. 1, pp. 79-92, 1993.

[41] M. E. Erkan, A. Vural, and T. Ozekinci, "Investigating the presence of Staphylococcus aureus and Coagulase Negative Staphylococci (CNS) in some leafy green vegetables," Research Journal of Biological Sciences, vol. 3, no. 8, pp. 930-933, 2008.

[42] M. N. Nipa, M. M. Reaz, M. M. Hasan et al., "Prevalence of multi drug resistant bacteria on raw salad vegetables sold in major markets of Chittagong City, Bangladesh," Middle-East Journal of Scientific Research, vol. 10, no. 1, pp. 70-77, 2011.

[43] P. Amoah, P. Drechsel, R. C. Abaidoo, and W. J. Ntow, "Pesticide and pathogen contamination of vegetables in Ghana's urban markets," Archives of Environmental Contamination and Toxicology, vol. 50, no. 1, pp. 1-6, 2006.

[44] S. M. Goyal, C. P. Gerba, and J. L. Melnick, "Occurrence and distribution of bacterial indicators and pathogens in canal communities along the Texas Coast," Applied and Environmental Microbiology, vol. 34, no. 2, pp. 139-149, 1977.

[45] E. Ikpeme, J. Nfongeh, M. E. Eja, L. Etim, and K. Enyi-Idoh, "Antibiotic susceptibility profiles of enteric bacterial isolates from dumpsite utisols and water sources in a rural community in cross river state," Nature and Science, vol. 9, no. 5, pp. 46-50, 2011.

[46] R. E. Godon, "The genus Bacillus," in Handbook of Microbiology, A. I. Laskin and H. A. Lechevalier, Eds., vol. 1-2, pp. 319-336, CRC Press, Cleveland, Ohio, USA, 1977.

[47] Codex Alimantarius, Code of Hygiene Practice for Fresh Fruits and Vegetables, Secretariateof the CODEX Alimetarius Commission, Joint FAO/WHO Food Standard programme, Vialedelle Terme di Caracalla, Rome Italy, 2007.

[48] J. Santamaría and G. A. Toranzos, "Enteric pathogens and soil: a short review," International Microbiology, vol. 6, no. 1, pp. 5-9, 2003. 
[49] K. J. Smith, R. Neafie, J. Yeager, and H. G. Skelton, "Micrococcus folliculitis in HIV-1 disease," British Journal of Dermatology, vol. 141, no. 3, pp. 558-561, 1999.

[50] M. A. Halablab, I. H. Sheet, and H. M. Holail, "Microbiological quality of raw vegetables grown in Bekaa Valley, Lebanon," American Journal of Food Technology, vol. 6, no. 2, pp. 129-139, 2011.

[51] J. M. Soriano, H. Rico, J. C. Moltó, and J. Mañes, "Assessment of the microbiological quality and wash treatments of lettuce served in University restaurants," International Journal of Food Microbiology, vol. 58, no. 1-2, pp. 123-128, 2000.

[52] D. O. Ukuku, C. Liao, and S. V. Gembeh, "Attachment of bacterial human pathogens on fruit and vegetable surfaces. Atlanta (États-Unis)," Journal of Applied Microbiology, vol. 98, pp. 380396, 2005.

[53] E. S. Donkor, T. Nortey, A. Opitan, N. Dayie, and M. L. Akyeh, "Antimicrobial susceptibility of Salmonella typhi and Staphylococcus aureus isolates and the effect of some media on susceptibility testing results," The Internet Journal of Microbiology, vol. 4, no. 2, pp. 1-5, 2008.

[54] H. Sina, F. Baba-Moussa, A. P. Kayodé et al., "Characterization of Staphylococcus aureus isolated from street foods: toxin profile and prevalence of antibiotic resistance," Journal of Applied Biosciences, vol. 46, pp. 3133-3143, 2011.

[55] J. Akbarmehr, "Antimicrobial resistance in Salmonella isolated from broiler chicken carcasses," African Journal of Microbiology Research, vol. 6, pp. 1485-1488, 2012.

[56] M. O. Cardoso, A. R. Ribeiro, L. R. Dos Santos et al., "Antibiotic resistance in Salmonella Enteritidis isolated from broiler carcasses," Brazilian Journal of Microbiology, vol. 37, no. 3, pp. 368-371, 2006.

[57] R. J. Ash, B. Mauck, and M. Morgan, "Antibiotic resistance of gram negative bacteria in rivers, United States of America," Emerging Infectious Diseases, vol. 8, no. 7, pp. 7-12, 2002.

[58] P. I. Umolu, E. N. Okoli, and I. M. Izomoh, "Antibiogram and beta-lactamase production of Staphylococcus aureus isolates from different human clinical specimens in Edo State, Nigeria," West African Journal of Medicine, vol. 21, no. 2, pp. 124-127, 2002.

[59] F. Mills-Robertson, S. S. Crupper, M. E. Addy, and P. Mensah, "Antibiotic resistance and genotyping of clinical group B Salmonella isolated in Accra, Ghana," Journal of Applied Microbiology, vol. 94, no. 2, pp. 289-294, 2003.

[60] L. van Vuuren, "Time running out as Africa sprints towards MDG deadline," The Water Wheel, vol. 9, no. 1, pp. 25-27, 2010. 

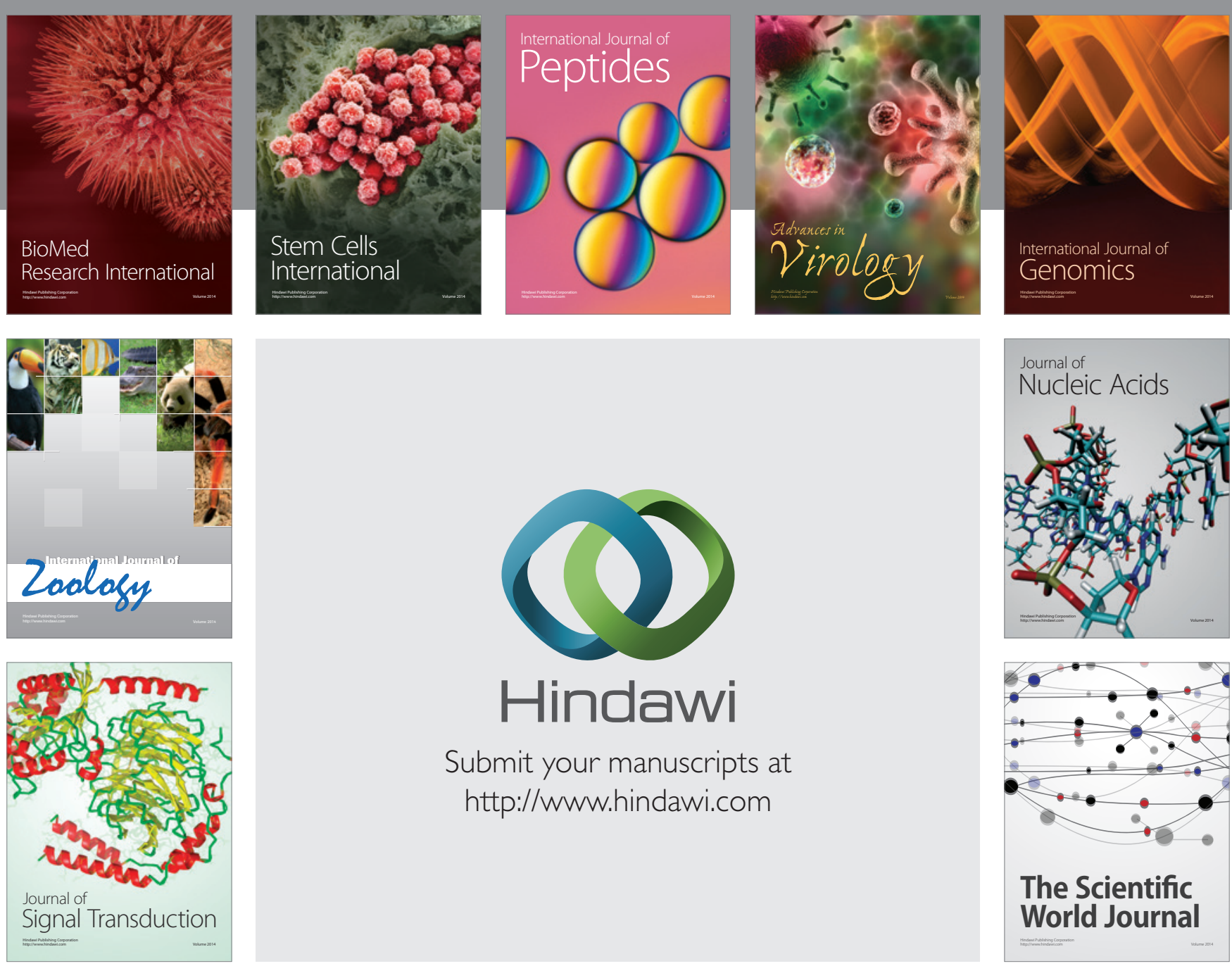

Submit your manuscripts at

http://www.hindawi.com
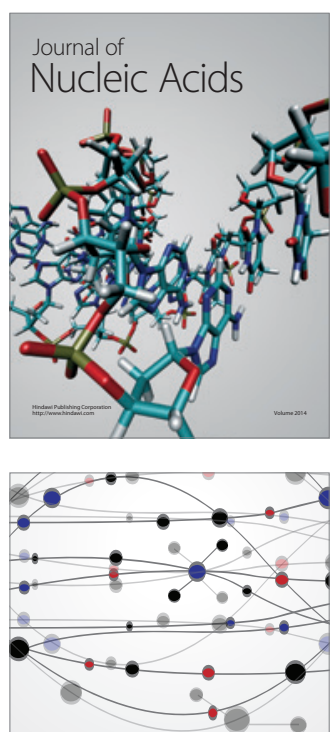

The Scientific World Journal
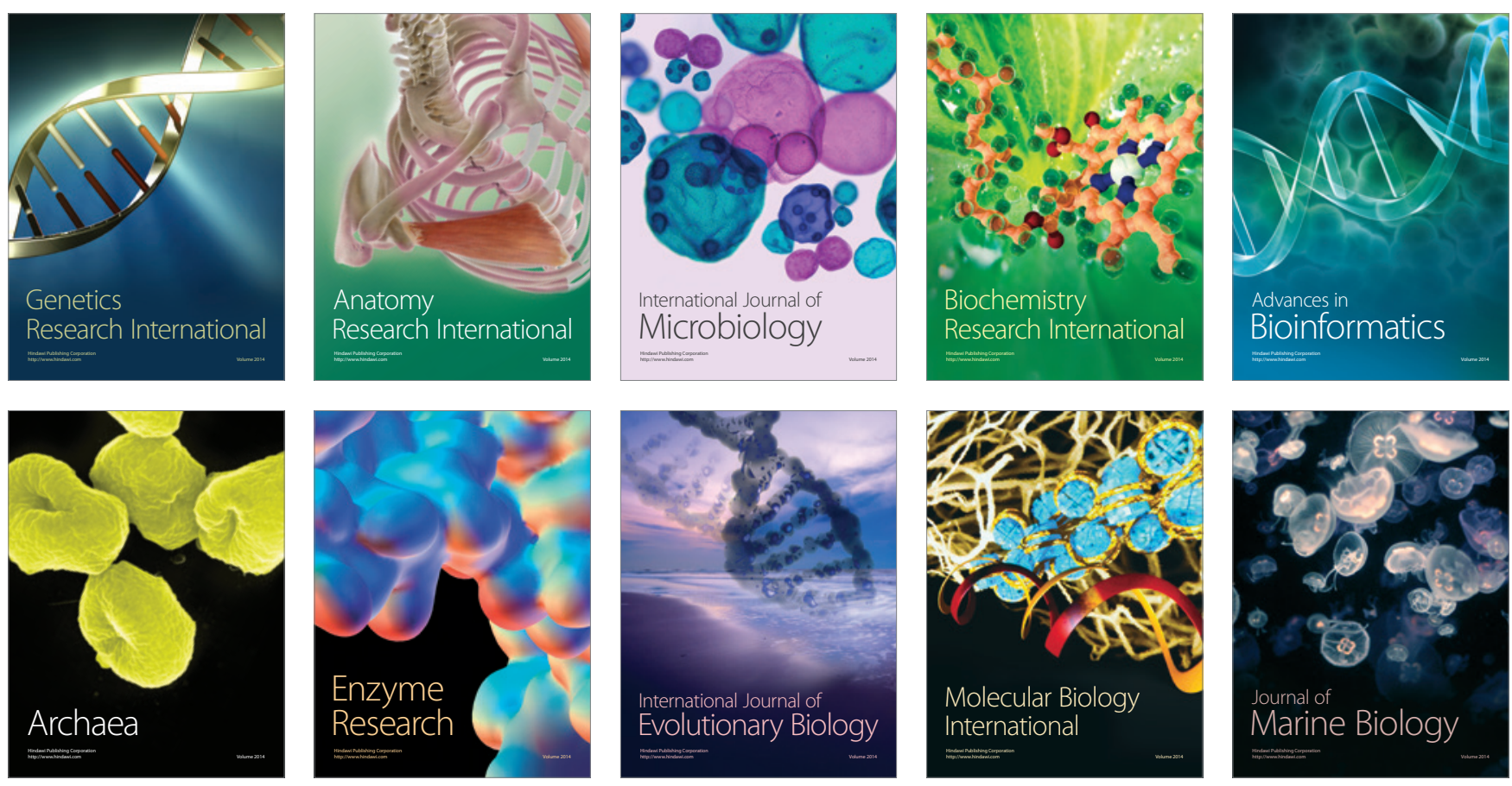